\title{
PEDUNCLE AND FRUIT YIELD, IN SIX CROPPING SEASONS, OF EARLY DWARF CASHEW TREE CLONES IRRIGATED WITH DIFFERENT WATER REGIMES ${ }^{1}$
}

\author{
KATHIA MARIA BARBOSA E SILVA², FRANCISCO AÉCIO GUEDES ALMEIDA, \\ PAULO SÉRGIO LIMA E SILVA ${ }^{4}$
}

\begin{abstract}
The objective of this work was to evaluate peduncle and fruit yield in clone MS 076 and in a clonal population of drip-irrigated, early dwarf cashew trees propagated by layering, in six cropping seasons. In order to meet the increased water requirements of the crop resulting from plant growth and development, irrigation during the dry season was performed daily according to the following water regime: $15 \mathrm{~min} / \mathrm{plant} /$ day during the 1 st year, $30 \mathrm{~min} /$ plant/day during the $2 \mathrm{nd}$ year, $45 \mathrm{~min} / \mathrm{plant} /$ day during the $3 \mathrm{rd}$ year and $60 \mathrm{~min} / \mathrm{plant} / \mathrm{day} \mathrm{during}$ all subsequent years. Water was supplied by one drip emitter/plant, at an (adjustable) flow rate of $36 \mathrm{~L} / \mathrm{h}$. The research was carried out in Fortaleza-Ceará, Brazil, and a random block design was utilized, with five replicates and split-plots. The clones were assigned to plots and the cropping seasons were considered as subplots. The clonal population was superior to the clone only with regard to number of nut shells (NNS), and solely in the first season. The clone was superior to the population as to NNS and peduncle yield (PY) in the second season, and also with regard to the three evaluated traits - NNS, PY, and nut shell yield, in the last three cropping seasons.
\end{abstract}

Index terms: Anacardium occidentale, cashew nut, cashew apple

\section{RENDIMENTOS DE PEDÚNCULOS E FRUTOS, EM SEIS SAFRAS, DE CLONES DE CAJUEIRO-ANÃO- PRECOCE IRRIGADOS COM DIFERENTES REGIMES HÍDRICOS}

RESUMO - O objetivo do trabalho foi avaliar, em seis safras, os rendimentos de pedúnculos e frutos do clone CP 076 e de uma População Clonal de cajueiro-anão-precoce, propagados por alporquia, irrigados por gotejamento. Visando a atender às maiores necessidades hídricas da cultura, decorrentes do crescimento e desenvolvimento das plantas, a irrigação, durante o período seco do ano, foi feita diariamente de acordo com o seguinte regime hídrico: 15 minutos/planta/dia durante o primeiro ano; 30 minutos/planta/dia durante o segundo ano; 45 minutos/planta/dia durante o terceiro ano, e 60 minutos/planta/dia durante os anos subseqüentes. A água foi fornecida através de uma torneira gotejadora/planta, com vazão (ajustável) de $36 \mathrm{~L} / \mathrm{h}$. O trabalho foi feito em Fortaleza-CE, utilizando-se do delineamento de blocos ao acaso, com cinco repetições e parcelas subdivididas. Os clones representaram as parcelas e as safras, as subparcelas. A População Clonal somente foi superior ao clone quanto ao número de castanhas (NC) e isto na primeira safra. O clone foi superior à População quanto ao NC e produtividade de pedúnculos (PP), na segunda safra, e quanto às três características avaliadas (NC, PP e produtividade de castanhas), nas três últimas safras.

Termos para indexação: Anacardium occidentale, castanha, caju

\section{INTRODUCTION}

The roots, stem, leaves, fruit and pedicels of the cashew tree (Anacardium occidentale L) are useful to man. However, the fruit and pedicels are the two most valuable parts from an economic point of view. Several types of juices and preserves can be obtained from the cashew tree's hypertrophied pedicels or pseudofruits. From the fruit or hard nut shell are extracted products such as the cashew nut $(\mathrm{CN})$, nut skins, the shell itself, and cashew nut shell liquid (CNSL), with economic emphasis on CN and CNSL.

The states of Ceará, Piauí and Rio Grande do Norte are responsible for $94 \%$ of cashew shell yield in Brazil (197,429 $t$, in the year 2000), in a cultivated area of 650 thousand hectares (Pessoa et al., 1995). This production generates 150 million dollars in cashew nut exports and creates thousands of jobs in different agroindustrial network activities (Pessoa et al., 1995). Despite being economically so important, nut shell yields in common cashew tree $(200 \mathrm{~kg} / \mathrm{ha})$ and early dwarf cashew tree orchards $(906 \mathrm{~kg} / \mathrm{ha}$ ) are small (Pessoa et al., 2000). Yield improvements can be obtained, obviously, through the development of new cultivars and more adequate cropping practices. Regarding the development of new cultivars, a special interest exists in evaluating clones (Oliveira et al., 1999; Oliveira et al., 2003; Paiva et al., 2002), because of the well-known advantages provided by vegetatively-propagated materials. In this respect, evaluating a mixture of clones can be advantageous as well; this can be referred to as a clonal population, which would result in less disease and pest problems and ensure a more steady yield than a population of plants bearing the same genotype.

The cashew tree is considered a resistant, drought-adapted plant, which explains why there is a lack of interest in investigating its response to irrigation (Oliveira et al., 2003). Several studies (Oliveira et al., 1998; Richards, 1992; Yadukumar, 1992) have shown, however, the benefits of irrigation for this crop. In addition, incentives received from the federal and state governments to foster irrigated fruticulture in the Brazilian northeastern region have increased the interest in irrigated cashew cropping.

Evaluation of early dwarf cashew tree genotypes shows that differences exist between clone progenies and between clones. Comparisons between progenies indicated differences between phenologies (Almeida et al., 1995a) and between fruit yields (Almeida et al., 1998a). Comparisons between clones indicated differences related to the number and weight of fruit, but not with respect to peduncle yield (Almeida et al., 2000). Oliveira et al (1999) and Oliveira et al (2003) also found differences between clones with regard to nut shell yield $(\mathrm{kg} / \mathrm{ha})$ in irrigated clones. It is interesting to point out that the response of early dwarf cashew trees to irrigation is genotype-dependent (Oliveira, 2002).

This research was aimed at evaluating peduncle and fruit yield in a clone and in a Clonal Population of drip-irrigated, early dwarf cashew trees propagated by layering, in six cropping seasons. In order to meet the increased water requirements of the crop resulting from plant growth and development, irrigation during the

\footnotetext{
(Trabalho 150/2003). Received: 09/10/2003. Accepted for publication: 13/10/2004.

${ }^{2}$ Agronomist, Ph.D., Prof. with Departamento de Biologia, UERN, Faculdade de Ciências Biológicas e Naturais, CP 130, Mossoró-RN, CEP 59.625-900. E-mail: kathiafanat@uern.br.

${ }^{3}$ Agronomist, Ph.D., Prof. with Departamento de Biologia, Centro de Ciências, Universidade Federal do Ceará. Rua Osvaldo Cruz, 250 - Apt ${ }^{\circ} 400$, Fortaleza-CE, CEP 60.125-150.E_mail: faecio@terra.com.br.

${ }^{4}$ Agronomist, Ph.D. Prof. with Departamento de Fitotecnia, ESAM, CP 137, Mossoró-RN, CEP 59625-900. E-mail: paulosergio@esam.br.
} 
dry season was performed daily according to the following water regime: $15 \mathrm{~min} / \mathrm{plant} /$ day during the 1 st year, $30 \mathrm{~min} /$ plant/day during the 2 nd year, $45 \mathrm{~min} / \mathrm{plant} /$ day during the $3 \mathrm{rd}$ year and $60 \mathrm{~min} / \mathrm{plant} /$ day during all subsequent years. Water was supplied by one drip emitter/plant, at an (adjustable) flow rate of $36 \mathrm{~L} / \mathrm{h}$.

\section{MATERIALAND METHOD}

The experiments were carried out in an area that belongs to Universidade Federal do Ceará (UFC), located $18 \mathrm{~km}$ from Fortaleza, at $3^{\circ} 41^{\prime} \mathrm{S}$ latitude and $35^{\circ} 43^{\prime} \mathrm{W}$ longitude. This region has two welldefined seasons: a rainy season, which occurs from January to July, with maximum rainfall in March and April, and a dry season, from August to December, with sporadic rainfall. According to Universidade Federal do Ceará (1997) the mean precipitation is 1642 $\mathrm{mm}$. The mean air temperature, based on data collected during 30 years, ranges from $23.5^{\circ} \mathrm{C}$ to $30.2^{\circ} \mathrm{C}$, with a compensated mean of $26.7^{\circ} \mathrm{C}$. The mean annual relative humidity is $79 \%$. The predominant climate in the region where the experiment area was located, according to Köppen's classification, falls into the AW' class (tropical rainy), or, according to Gaussen's classification, it is a $4 \mathrm{e}^{-\mathrm{TH}}$ (tropical hot with an attenuated drought). The mean annual temperature during the experimental period ranged from $26.3^{\circ} \mathrm{C}$ to $27.2^{\circ} \mathrm{C}$. The annual radiation ranged from 124,335 to $159,471 \mathrm{cal} / \mathrm{cm}^{2}$, while the annual precipitation ranged from 1042 to $3045 \mathrm{~mm}$ (Table 1).

TABLE 1 - Precipitation (mm) from January, 1990 to June, 1996. Fortaleza - Ceará, Brazil.

\begin{tabular}{lrrrrrrr}
\hline Months & \multicolumn{7}{c}{ Years } \\
\cline { 2 - 8 } & 1990 & 1991 & 1992 & 1993 & 1994 & 1995 & 1996 \\
\hline January & 126 & 162 & 36 & 43 & 183 & 188 & 157 \\
February & 72 & 256 & 352 & 108 & 476 & 278 & 251 \\
March & 175 & 438 & 305 & 199 & 687 & 662 & 665 \\
April & 201 & 618 & 238 & 231 & 583 & 894 & 402 \\
May & 207 & 164 & 49 & 132 & 225 & 407 & 226 \\
June & 55 & 73 & 133 & 70 & 663 & 190 & 67 \\
July & 121 & 8 & 10 & 180 & 116 & 46 & - \\
August & 82 & 13 & 30 & 32 & 19 & 6 & - \\
September & 42 & 1 & 18 & 12 & 26 & 0 & - \\
October & 16 & 53 & 7 & 6 & 5 & 9 & - \\
November & 21 & 5 & 3 & 13 & 6 & 19 & - \\
December & 35 & 0 & 2 & 17 & 56 & 0 & - \\
\hline Totals & 1,153 & 1,791 & 1,183 & 1,042 & 3,045 & 2,699 & 1,768 \\
\hline
\end{tabular}

The soil was classified as a sandy Abruptic Red-Yellow Argisol with a weak plinthic A horizon. The analysis of a soil sample indicated: $\mathrm{pH}=5.1,1.00 \mathrm{ppm} \mathrm{P}, 0.49 \% \mathrm{C}, 0.04 \% \mathrm{~N}$ and the following values for exchangeable cations (meq/100 g): $0.04 \mathrm{Ca}^{++}, 0.40 \mathrm{Mg}^{++}$, $0.22 \mathrm{~K}^{+}, 0.06 \mathrm{Na}^{+}, 0.80 \mathrm{H}^{+}$and $0.10 \mathrm{Al}^{+++}$.

During the dry season, the plants were watered by drip irrigation, using a drip emitter (flow of 36 liters water/hour). Irrigation was performed daily according to the following watering shifts: 15 $\mathrm{min} /$ (plant.day) during the $1 \mathrm{st}$ year, $30 \mathrm{~min} /$ (plant.day) during the 2nd year, $45 \mathrm{~min} /($ plant.day) during the $3 \mathrm{rd}$ year and $60 \mathrm{~min} /$ (plant.day) during all subsequent years. The analysis of the class $\mathrm{C}_{3} \mathrm{~S}_{1}$, highly saline, non-sodic water (Richards, 1954) utilized for irrigation indicated: $\mathrm{EC} 25^{\circ} \mathrm{C}=0.9 \mathrm{mmhos} / \mathrm{cm} ; \mathrm{pH}=6.8, \mathrm{Ca}^{++}=1.7$ $\mathrm{meq} / \mathrm{L} ; \mathrm{Mg}^{++}=3.5 \mathrm{meq} / \mathrm{L} ; \mathrm{K}^{+}=0.3 \mathrm{meq} / \mathrm{L} ; \mathrm{Na}^{+}=3.4 \mathrm{meq} / \mathrm{L} ; \mathrm{Cl}=7.8$ $\mathrm{meq} / \mathrm{L} ; \mathrm{CO}^{2-}=0.0 \mathrm{meq} / \mathrm{L} ; \mathrm{HCO}^{3-}=1.2 \mathrm{meq} / \mathrm{L} ; \mathrm{SO}^{2-}=0.0 \mathrm{meq} / \mathrm{L}$; sodium adsorption ratio $=2.1 \mathrm{meq} / \mathrm{L}$.

Two populations, obtained by layering, were planted in January 1990, in a random block design with three replicates. One of the populations was from the CP 076 clone, developed by Empresa de Pesquisa Agropecuária do Ceará (EPACE); the other population was obtained by Universidade Federal do Ceará, consisting of clones from five different matrices, selected based on their fruit yield and quality. For simplification, the first population will be hereafter referred to as the CP 076 clone and the second as the Clonal Population. Each plot originally consisted of four plants grown at a $6 \mathrm{~m} \times 3 \mathrm{~m}$ spacing. This planting density was maintained until the third year (1990 to 1992). In 1992, plants had grown to an extent that caused mutual shading, making it necessary to eliminate one plant in each row, alternately. Therefore, starting at the fourth year, the plants were grown at a row spacing of $6 \mathrm{~m} \times 6 \mathrm{~m}$.

The management practices consisted of two hoeings and one mowing performed each year. Disease and pest control were performed when necessary.

The numbers and weights of peduncles and fruits were evaluated through two weekly harvests. Peduncles were weighted after they were harvested, while nut shells were weighted after being placed in the sun for $48 \mathrm{~h}$. During the rainy season, the nut shells were placed to dry in an oven at $37^{\circ} \mathrm{C}$ for $48 \mathrm{~h}$, before weighting. The data were analyzed by the analysis of variance method (Zar, 1999), and two aspects were considered. Data obtained from the $1^{\text {st }}$ through the $3^{\text {rd }}$ year represented one experiment and data from the $4^{\text {th }}$ through the $6^{\text {th }}$ year represented another experiment. In each experiment, genotypes were considered as plots and years or cropping seasons were considered as subplots. In other words, the experiments were considered to have been carried out in a split-plot design.

\section{RESULTS AND DISCUSSION}

There was a significant effect of cropping seasons (S) and of the clones $(\mathrm{C}) \times$ cropping seasons $(\mathrm{S})$ interaction, on the numbers of nut shells and peduncles, at the row spacing of $6 \mathrm{~m} \times 3 \mathrm{~m}$ (Table 2). The Clonal Population was superior to clone MS 076 in the first cropping season. The opposite occurred in the second cropping season, and in the third cropping season there was no difference between clones. The 1991/92 and 1992/93 cropping seasons were not different among themselves and were superior to the 1990/91 cropping season, for both clones. Therefore, the differential behavior of the two clones, in the first two cropping seasons, caused the clones $\times$ cropping seasons interaction.

As to nut shell yield in $\mathrm{kg} / \mathrm{ha}$, there was a significant effect of cropping seasons (S), but no significant effect of clones (C) or of the $\mathrm{S} \times \mathrm{C}$ interaction was observed, at the $6 \mathrm{~m} \times 3 \mathrm{~m}$ row spacing (Table 2). Yield in the 1992/93 cropping season was superior to that obtained in the 1990/91 cropping season, and yield in the 1991/92 cropping season was superior to the yield obtained in the other two cropping seasons (Table 2).

TABLE 2 - Means for number of nut shells (or peduncles), nut shell yields and peduncle yields of a clone and a clonal population of irrigated early dwarf cashew trees, at a $6 \mathrm{~m} \times$ $3 \mathrm{~m}$ row spacing, in the first three cropping years. Fortaleza - Ceará, Brazil.

\begin{tabular}{|c|c|c|c|c|}
\hline \multirow[t]{2}{*}{ Clones } & \multicolumn{3}{|c|}{ Cropping season $^{1}$} & \multirow[t]{2}{*}{ Mean } \\
\hline & $1990 / 91$ & $1991 / 92$ & $1992 / 93$ & \\
\hline \multicolumn{5}{|c|}{ Number of nut shells (or peduncles) ha } \\
\hline CP 076 & 13,689 b B & 214,606 a A & 188,970 a $\mathrm{A}$ & - \\
\hline Population & 27,102 a B & 152,113 b A & 167,245 a A & - \\
\hline Means & 20,395 & 183,359 & 272,592 & - \\
\hline \multicolumn{5}{|c|}{ Nut shell yields $\left(\mathrm{kg} \mathrm{ha}^{-1}\right)$} \\
\hline CCP-076 & 104 & 1,566 & 1,353 & $1,008 \mathrm{a}$ \\
\hline Population & 208 & 1,276 & 1,333 & $939 \mathrm{a}$ \\
\hline Means & $156 \mathrm{C}$ & $1,421 \mathrm{~A}$ & $1,343 \mathrm{~B}$ & 974 \\
\hline \multicolumn{5}{|c|}{ Peduncle yields $\left(\mathrm{kg} \mathrm{ha}^{-1}\right)$} \\
\hline CP-076 & 1,038 a B & 20,891 a $\mathrm{A}$ & 16,181 a $A$ & - \\
\hline Population & 2,012 a B & $11,001 \mathrm{~b} \mathrm{~A}$ & 12,115 a A & - \\
\hline Mean & 1,525 & 15,946 & 14,148 & - \\
\hline
\end{tabular}

${ }^{1}$ Means followed by the same lower case letter, in the columns, and by the same upper case letter, in the row, do not differ among themselves, at 5\% probability, by Tukey test. 
With regard to peduncle weight, there was a significant effect of clones (C), cropping seasons and of the $\mathrm{C} \times \mathrm{S}$ interaction, at the $6 \mathrm{~m} \times 3 \mathrm{~m}$ row spacing (Table 2). There was no difference between clones in the 1990/91 and 1992/93 cropping seasons, but in the 1991/92 cropping season clone MS 076 was superior to the Clonal Population. As in the case of the numbers of nut shells and/or peduncles, the peduncle yields in $\mathrm{kg} / \mathrm{ha}$ for the 1991/92 and 1992/93 cropping seasons were not different among themselves and were superior to yield in the 1990/91 cropping season. The similar behavior of both clones in the 1990/91 and 1992/93 cropping seasons, in addition to the superiority of clone MS 076 in the 1991/92 cropping season were determinative of the clones $\times$ cropping season interaction.

There was a significant effect of cropping seasons (S) and clones (C), but not of the $\mathrm{C} \times \mathrm{S}$ interaction, on the numbers of nut shells (or peduncles), at the $6 \mathrm{~m} \times 6 \mathrm{~m}$ row spacing (Table 3 ). Clone MS 076 was, on average, superior to the Clonal Population in the three cropping seasons. Yield in the 1995/96 cropping season (the last one in this study) was superior to the fifth season which, in turn, was superior to the fourth.

TABLE 3 - Means for number of nut shells (or peduncles), nut shell yields and peduncle yields of a clone and a clonal population of irrigated early dwarf cashew trees, at a $6 \mathrm{~m} \times$ $6 \mathrm{~m}$ row spacing, from the fourth to the six cropping year. Fortaleza-Ceará, Brazil.

\begin{tabular}{lcccc}
\hline Clones & \multicolumn{3}{c}{ Cropping season $^{1}$} & \multirow{2}{*}{ Mean } \\
\cline { 2 - 4 } & 1993/94 & $1994 / 95$ & $1995 / 96$ & \\
\hline \multicolumn{5}{c}{ Number of nut shells (or peduncles) ha } \\
\hline CP 076 & 236,895 & 281,996 & 421,854 & $313,582 \mathrm{a}$ \\
Population & 176,141 & 148,151 & 239,438 & $187,910 \mathrm{~b}$ \\
Means & $206,518 \mathrm{C}$ & $215,074 \mathrm{~B}$ & $330,646 \mathrm{~A}$ & 250,746 \\
\hline \multicolumn{5}{c}{ Nut shell yields $\left(\mathrm{kg} \mathrm{ha}^{-1}\right)$} \\
\hline CCP-076 & 1,651 & 1,723 & 2,893 \\
Population & 1,314 & 1,103 & 2,021 & $2,089 \mathrm{a}$ \\
Means & $1,483 \mathrm{~B}$ & $1,413 \mathrm{~B}$ & $2,457 \mathrm{~A}$ & $1,779 \mathrm{~b}$ \\
\hline \multicolumn{5}{c}{ Peduncle yields $\left(\mathrm{kg} \mathrm{ha}^{-1}\right)$} \\
\hline CP-076 & 22,864 & 17,902 & 22,572 \\
Population & 12,880 & 13,796 & 16,279 & $21,113 \mathrm{a}$ \\
Mean & $17,872 \mathrm{~A}$ & $15,849 \mathrm{~A}$ & $19,426 \mathrm{~A}$ & $17,715 \mathrm{~b}$ \\
\hline
\end{tabular}

${ }^{1}$ Means followed by the same lower case letter, in the columns, and by the same upper case letter, in the row, do not differ among themselves, at 5\% probability, by Tukey test.

With regard to nut shell yield expressed as $\mathrm{kg} / \mathrm{ha}$, there was a significant difference both for cropping seasons and for clones, at the $6 \mathrm{~m} \times 6 \mathrm{~m}$ row spacing (Table 3 ). The 93/94 cropping season did not differ from the 94/95 cropping season, while the 95/96 cropping season was superior to both. Clone MS 076 was significantly more productive than the Clonal Population.

As to peduncle yield, expressed in $\mathrm{kg} / \mathrm{ha}$, there was a significant effect of clones (C) only, at the $6 \mathrm{~m} \times 6 \mathrm{~m}$ row spacing (Table 3). Clone MS 076 was superior to the Clonal Population. Oliveira (2002) also observed a superiority of clone MS 076 with regard to peduncle yield.

When the yields of peduncles and nut shells for the clone and Clonal Population are analyzed, in the six cropping seasons, it can be verified that: (1) the number of nut shells and peduncles for clone MS 076 was inferior in the 90/91 cropping season, equal in the 92/93 season, and superior to the clonal population in the other cropping seasons; (2) peduncle yield for clone MS 076 was identical as for the clonal population in the 90/91 and 92/93 cropping seasons, and superior in the other cropping seasons; and (3) nut shell yield for clone MS 076 was superior to the Clonal Population yield in the last three cropping seasons (93/94, 94/95 and 95/96), and equal in the preceding cropping seasons.

The total number of nut shells and/or peduncles yielded by clone MS 076 in the six cropping seasons was 1,356,183, while the number yielded by the clonal population was only 910,190 , meaning a $49 \%$ superiority of clone MS 076 over the population. With respect to nut shell yield, the superiority of clone MS 076 over the clonal population was only $28 \%(9,287 \mathrm{~kg} / \mathrm{ha}$ as compared to $7,255 \mathrm{~kg} / \mathrm{ha})$. As to peduncle yield, clone MS 076 yielded $101,438 \mathrm{~kg} / \mathrm{ha}$, while the Clonal Population only yielded $68,079 \mathrm{~kg} / \mathrm{ha}$ (a $49 \%$ superiority).

The data shown in Tables 2 and 3 still allow us to observe that cropping seasons can differentially influence the number of peduncles, and peduncle and nut shell weights. In the first three cropping seasons (Table 2), the environment influence on the two clones was similar with regard to the number of peduncles and/or nut shells, and to peduncle weight, but different with regard to nut shell weight. That is to say, there was no difference between the 91/ 92 and 92/93 cropping seasons for the first two traits, and both surpassed the 90/91 cropping season. However, with respect to nut shell weight, as previously mentioned, there were differences between those three cropping seasons. In the last three cropping seasons (Table 3), the environmental influence was different for the three traits. Differences between cropping seasons, similar to those observed in the present work, were observed by other authors (Oliveira et al., 1999; Oliveira et al., 2003).

The adoption of different water regimes in different years did not seem to have directly influenced the evaluated characteristics. In each of the first three years, when plants received progressively higher amounts of water, differences between the three cropping seasons were observed only with regard to nut shell yield (Table 2). With respect to the other characteristics (Table 2), no differences were observed between the 1991/92 and 1992/93 cropping seasons. On the other hand, in the last three cropping seasons (Table 3 ) there were differences between cropping seasons with regard to nut shell numbers and yield, even though the same amount of water was used for irrigation. A similar discussion can be made with respect to rain water (Table 1). In the first three cropping seasons, the year with the most rain was 1991, but the 1991/92 cropping season only differed from the 1992/93 season with regard to nut shell yield (Table 2). In the last three cropping seasons, the year with the most rain was 1994, but both the number of nut shells and nut shell yield were higher in the 1995/96 cropping season. What might have happened is that both rain and irrigation water provided continued growth of the above-ground part of the plant and of its root system, causing the formation of more flowers, which resulted in higher peduncle and fruit yields. It is obvious that an interaction between environmental factors must exist, making it difficult to separate the effects of each factor.

The fact that clone MS 076 was equal or inferior to the Clonal population, in the first three cropping seasons (Table 2), for some traits related to peduncle and nut shell yields, but was always superior to the Clonal Population, in the last three cropping seasons (Table 3), as to all peduncle and nut shell yield traits, might indicate a greater adaptation of clone MS 076 to wider row spacings.

Almeida et al. (2000), working with irrigated plants grafted from clones MS 1001 and 076, verified that the mean nut shell and peduncle yields for clone MS 1001 were always superior to clone MS 076, except in the $1^{\text {st }}$ year. However, the analysis of variance did not show significant differences between the mean peduncle yields for the two clones being studied, but revealed a significant difference between their mean nut shell yields in their $6^{\text {th }}$ year of life. With regard to this, Almeida et al. (1998b), comparing nut shell and peduncle yields of progenies from clones MS 076 and 1001, under irrigation conditions, verified the superiority of progeny 076 over 1001 


\section{CONCLUSIONS}

The Clonal Population was superior to the clone only with regard to number of nuts (NN), and solely on the first season. The clone was superior to the Population as to $\mathrm{NN}$ and peduncle yield (PY) in the second season, and also with regard to the three evaluated traits - NN, PY, and nut yield, in the last three cropping seasons.

\section{REFERENCES}

ALMEIDA, F. A. G.; ALMEIDA, F. C. G; NUNES, R. DEP.; CARVALHO, P. R. DE; MENESES JR., J. Estudos fenológicos de plantas enxertadas de cajueiro anão sob condições de irrigação. Revista Brasileira de Fruticultura, Jaboticabal, v. 17, n. 2, p. 71-84, 1995.

ALMEIDA, F. A. G.; ALMEIDA, F. C. G.; MARTINS JR., W.; MENESES JR., J.; CARVALHO, P. R. de. Produtividade potencial de plantas enxertadas de cajueiro anão (Anacardium occidentale L.) em condições de irrigação. Revista Brasileira de Fruticultura, Jaboticabal, v. 20, n. 3, p. 343-358, 1998a.

ALMEIDA, F. A. G.; SILVA, A. Z.; ALMEIDA, F. C. G. ; MARTINS JR., W.; MENESES JR., J. Comparação dos parâmetros de produção de duas progênies de cajueiro anão sob condições de irrigação. Revista de la Faculdad de Agronomia, Maracay, v. 24, n. 1, p.59-77, 1998 b.

ALMEIDA, F.A.G.; MARTINS JUNIOR, W.; ALMEIDA, F.C.G., MENÊSES JUNIOR, J. Ecologia comparativa da produção de dois clones enxertados de cajueiro anão quando em condições de irrigação. Revista de la Faculdad de Agronomia, Maracay, v. 26, n. 1, p.91-105, 2000.

OLIVEIRA, V.H. de. Influência da irrigação na produção de pedúnculo e de castanha em clones de cajueiro-anão-precoce. Revista Brasileira de Fruticultura, Jaboticabal, v.24, n.3, p.717-720, 2002.

OLIVEIRA, V.H.; CRISÓSTOMO, L.A.; MIRANDA, F.R. de; ALMEIDA, J.H.S. Produtividade de clones comerciais de cajueiro anão precoce (Annacardium occidentale L.) irrigados no Município de Mossoró-RN. Fortaleza: Embrapa-CNPAT, 1998. 6p. (Comunicado Técnico, 14)

OLIVEIRA, V.H. de MIRANDA, F.R. de; SANTOS, F.J. de S.; LIMA, R.N. de; MONTENEGRO, A.A.T.; CRISÓSTOMO, L.A. Comportamento de clones de cajueiro anão precoce sob diferentes regimes de irrigação. Agrotrópica, Ilhéus, v.11, n.2, p.63-66, 1999.

OLIVEIRA, V.H. de; BARROS, L. de M.; LIMA, R. N. de. Influência da irrigação e do genótipo na produção de castanha em cajueiroanão-precoce. Pesquisa Agropecuária Brasileira, Brasília, v.38, n.1, p.61-66, 2003.

PAIVA, J.R. de; CARDOSO, J.E.; BARROS, L. de M.; CRISÓSTOMO, J.R.; CAVALCANTI, J.J.V.; ALENCAR, E. da S. Clone de cajueiroanão precoce BRS 226 ou Planalto: nova alternativa para o plantio da região semi-árida do Nordeste. Fortaleza: Embrapa, 2002. 4p. (Comunicado Técnico, 78).

PESSOA, P.F.A.P.; OLIVEIRA, V.H.; SANTOS, F.J.S.; SEMRAU, L.A.S. Análise da viabilidade econômica do cultivo do cajueiro irrigado e sob sequeiro. Revista Econômica do Nordeste, Fortaleza, v.31, n.2, p.178-187, 2000.

PESSOA, P.F.P., LEITE, L.A. de S., PIMENTEL, C.R.M. Situação atual e perspectivas da agroindústria do caju. In: ARAÚJO, J.P.P, SILVA, V.V. (Org.). Cajucultura: modernas técnicas de produção. Fortaleza: Embrapa-CNPAT, 1995. p.23-42.

RICHARDS, N.K. Cashew tree nutrition related to biomass acumulation, nutrient composition and nutrient cycling in sandy red earths of Northern Territory, Australia. Scientia Horticulturae, Amsterdam, v.52, p.125-142, 1992.

UNIVERSIDADE FEDERALDO CEARÁ. Centro de Ciências Agrárias. Estação Meteorológica do Centro de Ciências Agrárias. Dados meteorológicos. Fortaleza, 1997. (Documentos, s.n.)

YADUKUMAR, N. Economic feasibility of microirrigation (drip irrigation) and graded doses of NPK on the productivity of cashew. Karnataka, India: National Research Centre for Cashew, Annual Report 1991-1992.p.21

ZAR, J.H. Biostatistical analysis. 4.ed. Upper Saddle River: Prentice Hall, 1999. 663p. 